Chapter 2

\title{
Entrepreneurship Education for Women in Brazil - Challenges and Limits
}

\author{
Elaine da Silveira Leite \\ Additional information is available at the end of the chapter \\ http://dx.doi.org/10.5772/59038
}

\section{Introduction}

A brief socioeconomic literature review, approaching economic, political and social analyses, reveals that Brazilian society has distinctive characteristics, in which the emergence of new economic agents and institutions are responsible for disseminating financial activities and entrepreneur practices in the country. The Brazilian financial market has developed several institutions to create a stable environment encouraging savings and investment from the majority of the population who are unable, unfamiliar with or were marginalized by the financial system.

It is possible to observe a serious of actions that were important for the development of the Brazilian economic scenario; and, it is also significant highlighted that this events were particularly emphasized in Brazilian media as being essential for economic growth. These included some procedures about providing new laws for corporations; offering protection for minority shareholders ${ }^{1}$; strengthening of Securities and Exchange Commission of Brazil, whose activities were restructured to support financial market development ${ }^{2}$; establishing benefits for companies that adopt the corporate governance practices launched by the Brazilian Development Bank ${ }^{3}$; and the creation of a capital market plan ${ }^{4}$ to guarantee the sustainability of the stock market. These recent events have brought security and ensured the creditability of the Brazilian financial market ${ }^{5}$.

\footnotetext{
1 Data taken from: Adriana Dias, "Impactos positivos da nova lei das Sociedades Anônimas". Empreendedor. 15 Fev. 2008. Web. 10 Aug. 2009. <http://www.empreendedor.com.br/codigo=6596>

2 Data taken from: “FIDC: novas instruções da CVM devem trazer mais proteção ao investidor." Administradores. 12 Dec. 2006. Web. 10 Aug. 2009. <http://www.administradores.com.br/informe-se/informativo/fidc-novas-instrucoes-dacvm-devem-trazer-mais-protecao-ao-investidor/8663/>
} 
Therefore, in April 2008, Brazil was classified as investment grade. It suggests that the country was regarded as having low risk of default and the nation is safe to receive investment ${ }^{6}$. Consequently, the news affected the stock market and its index registered a new record score $^{7}$. It is also important to mention that Brazil also received substantial investment by foreign investors, as a consequence of the world attention focused on the BRIC's (Brazil, Russia, India and China $)^{8}$.

At least, Brazil symbolically won a great position in the international scenario and it is seen as a virtuous economic, political and legal environment. In this scenario, new agents emerged; they are considered financial intermediaries that entice ordinary people to became entrepreneur and encourage them to the finance field through different activities such as production of books, lectures and coaches. In this sense, it is attractive to present theses intermediates and their activities, because this makes it possible to understand how some actors are able to bring individuals into new economic practices.

The Brazilian economy context allowed the emergence of new actors. They are moral entrepreneurs of finance, educating on ways to invest honestly to achieve economic success, even during times of crisis. By capitalizing on volatility and uncertainty, they educate how instability can be the best time for the development of economic skills.

The expansion of this culture of investment is popularized and connected with models of selfhelp. This phenomenon has been consolidated into a new model of society that supports the growth of the entrepreneur and financial practices in Brazil and it legitimatizes personal economic activities.

3 Data taken from: Catherine Vieira. “Os pioneiros da governança corporativa”.Valor Econômico 29 Jun. 2004. Web. 10 Aug. 2009. <Http://www.lavca.org/lavca/allpress.nsf/0/966BC1542A814BDA86256EC6001EF760>

4 Data taken from: "Plano Diretor do Mercado de Capitais, o que muda para o investidor?" Portal Acionista. 10 Aug. 2009. Web. 10 Aug. 2009. <http:// www.acionista.com.br/dep_tecnico/070809_plano_diretor.htm>

5 It is important to mention Apolinárioet al. (2002) who states that the Brazilian government has adopted new strategies to make the national stock market stronger. The "desestatização", which has been observed for the last years by selling government's stocks from the two biggest Brazilian companies, Petrobras and the Companhia Vale do Rio Doce, represents the last stage of privatization process, which was initiated in 1997. This process is called "Stock Market Democratization". The success in moving funds from FGTS (Time Service Warranty Funds) to Petrobras Privatization Mutual Funds (FMP) made Brazilians' interest in investing their money into the FMPCVRD increase greatly, causing the biggest stock sale operation that has ever happened in Brazil.

6 Data taken from: Claudia Violante, “Após grau de investimento, Bovespa bate recorde histórico". Agência Estado, 30 Apr. 2008: Economic Section. Print.

7 (Bovespa) Stock Exchange Index. Data taken from: Bovespa. 10 May 2008. Web. 10 Aug. 2009 <http://www.bmfbovespa.com.br/indices>

8 Data taken from: Anne Warth and Francisco Carlos de Assis, "Brasil é o 10o em ranking mundial de investimento estrangeiro." Agência Estado 17 Sep. 2009. Web. 10 Nov. 2009. <http://www.estadao.com.br/noticias/economia,brasil-eo-10-em-ranking-mundial-de-investimento-estrangeiro,436642,0.htm> 
This paper presents some recent literature on aspiring female entrepreneurs in order to argue about the social (re)signification that relates the role of women in family and society, approaching the transformation of evaluative concepts that surround the socio-economic life of women through books and websites that encourages entrepreneurship and economic decision practices to reach financial independence.

\section{State and new economic practices}

The debate about the role of the State and the economy in Brazil led to a series of studies, mainly from the 1980s, and it continues at present, especially about the state's role such as regulation and deregulation issues (Evans, 1995). Overall, the 1980s were characterized by a neo-conservative wave and its proposal of a minimal state. In 1990s, when the neoliberal proposal became less acceptable, the movement toward reform, or more specifically, the state reconstruction began to be a dominant program (Bresser-Pereira, 1997). According to BresserPereira and Grau (1999), the globalization process from the 1990s also required new methods of more efficient public administration; consequently, it increased the importance of new actors to implement social services that was guaranteed by the State.

At this same time, the State was seen as inefficient and corrupt, in which political and economic reforms were being discussed to change this scenario. However, this situation created a new dynamic, which provided the rise of new agents and organizations, for example, the growth of non-governmental organization (NGOs) and self-help groups that were concerned about bringing social and economic development to Brazilian nation (Bresser-Pereira; Grau, 1999).

These developments help us understand not only the reform of the State but also the development of the Brazilian financial market and the emergence of corporate governance issues in Brazil (Grün, 2003). Corporate governance, which is shaped by the financial sphere, appeared as a requirement for transparency via society, emerging as a criticism of the Brazilian bureaucratic model. The corporate governance movement was supported during the Fernando Henrique Cardoso government (1995-2002) and was tied to the privatization issues, because talking about transparency was essential to warm up the capital market and to attract investors. The government needed to be transparent to increase investors' confidence in the privatization process, which means that the government was required to adopt corporate governance to be perceived as transparent institution (Grün, 2003).

Carvalho (2002) argues that it is possible to observe modifications of institutional investor's attitudes during the Fernando Henrique Cardoso government. As a result, important facts emerge, such as, the internationalization of the Brazilian capital market, the increasing number of companies accessing international market through American Depositary Receipt (ADR) the opening of the financial system for multinational institutions, and the increasing importance of foreign investors in the domestic stock market. 
In 2002, the principal candidate for the Presidency, Luiz Inácio Lula da Silva, who represents the left and unionism, went to Bovespa (the principal stock exchange in Brazil). At that time, he wanted to demonstrate adherence to economic and corporate governance practices established in the financial market. As a symbolic approach, it is possible to argue that corporate governance has gained huge attention in the nation (Grün, 2003).

It is important to highlight, according to Sá (2003), that the corporate governance discourse is associated with economic progress, and that the financial actors claim that it is through the economic growth that Brazilian society will achieve social development. In general, social and economic development became to be seen as part of the same political approach.

Therefore, corporate governance becomes a great solution for Brazilian society. It is recognized not only as a neoliberal prescription to solve the problem of companies' capitalization, but also as a means to enlarge both financial markets, and the Brazilian economy and social field (Grün, 2004).

In this sense, Brazil, like other emerging nations, is experiencing rapid financialization. This process is shaped by financial changes in the global financial market and involves restructuring of the country's financial organization through privatization, fiscal and monetary reform and the creation of new programs and institutions that encourage economic growth and popular investment (Grün, 2009). Financialization includes not only financial intermediaries but also self-help deals (Leite, 2012).

The financialization processes is formed by an interesting dynamic in Brazil, in which corporate governance practices gain significance in the context of the critique of the inefficient state. Here, it is possible to observe the rise of new economic actors that appeared as a solution to change the "uncertainty" of the economic and political scenarios.

Thus, the pathway of corporate governance, which goes through the economic and political issues to the capital market in Brazil, opens a new way to understand how actors try to change the traditional perception of the market through their symbolic strategies (Grün, 2007). Moreover, regarding the popularization of financial market issues, the Brazilian state is watching its expansion, but to some extent, without control over the situation.

At the same time, that the financial market is being reshaped, it is possible to notice the rise of personal finance and entrepreneurial discourses that it is linked to self-help schemes in Brazil. An interesting evidenece of this scenario comes from the bookstores' shelves that are filled with books and releases that deal with money and financial advices.

McGee (2005) explains that in a period of declining security, there is no surprise if one finds a marked increase in the number of self-help titles. In this way, McGee emphasizes how the promise of self-help can lead individuals into a new sort of enslavement, into a cycle where the self is not improved but endlessly belabored.

Simultaneously, it allocates to the individual sphere the need to rely on private financing, rather than relying on the government. It formed the basis for the development of a new way of thinking in Brazil, the stimulus to economic growth by individuals through the ideals of self-help, that means - "if success is solely the result of one's own efforts, then the responsibility 
for any failure must necessarily be individual shortcomings or weaknesses" (McGee, 2005:13). This movement seeks to reach the general population, it is not restricted to a portion of society able to innovate, save and invest in the markets.

\section{Interlocking: Entrepreneur, personal finance and women}

In Brazil, Paula and Wood Jr. (2003) highlight that the first signs of demand for personal finance issues were noted after the release of the books: Your Financial Future ${ }^{10}$ and Rich Dad, Poor Dad.

Among the list of publications related to personal finance, there are several books directed to women, for example, "Rich Woman - the investment guide for Women". The formula she uses is her "husband's idea" - he is the author of Rich Dad, Poor Dad. She employs her own history of life to teach how to be financially independent. Other illustration is the book: Normal Girls Go Shopping; Expert Girls Go to the Stock Market written by Brazilian authors -; they advertise "You do not know, but you were made to invest". The authors focus on how women are educated to hate money ${ }^{11}$. In general, the advices for women emphasize that women do not enrich because they focus on needs of others rather than on themselves. Consequently, these facts prevent women from becoming independent.

These books follow a model that structures a kind of "cultural guide", in which enhances questions about conspicuous consumption, biological and social women's periods like - career, marriage, children, divorce, boyfriend, pregnancy, etc. By the way, it is important to observe that they emphasize the quest for financial independence, but highlight issues that lead to the idea of housekeeping and family.

The book titled "Smart woman: (...) makes investments" ${ }^{12}$ is a typical example. The narrative focus on issues related to career and indicated some steps to achieve financial independence, but it also highlighted that women could not forget how to be a good mother and a respectable housewife. The author emphasizes the needed for women to think of theirselves, but also points to their traditional role in family.

In general, these publications also deal with traditional housekeeping like shopping, caring children and family. These subjects appeared associated with issues like financial planning, credit cards, and investments as guidelines to motivate them to set goals and to manage time, money and other resources as central entrepreneurship skills to achieve financial independence.

In this sense, several reports about the increasing number of women participation in markets and their relationship with money were found in a range of economic Brazilian newspaper ${ }^{13}$. Some reports mention it as a new phenomenon that were being occurred, mostly in the upper

10Free translation made by the author.

11 Ibid.

12 Ibid. 
middle classes - it shows that some women left their professional life to manage the family's assets. As presented in the quote below:

(...) she is graduated in marketing management. Main Occupation "home broker." That's how she defines herself. Three years ago, she started managing the family financial assets. She was encouraged by her husband, a mechanical engineer who works in the area of power generation. She attended a seminar of the "Women in Action," realized by Bovespa. Since then, she has managed the couple's investments. She is happy, because she is watching the multiplication of their money ${ }^{14}$.

In this scenario, the São Paulo Stock Exchange leads a program directed to female entrepreneurs - it is called "Women in action" (2003). The project was designed to give women the step-by-step guidance to learn about business plan. It also elucidates demands about budget skills, and presents advices about financial options and requirements.

This fact is clear more evident, when it focus on Sebrae (Brazilian government agency that provides support to micro and small enterprises) that encourages women of all social classes to became entrepreneur. For example, the "Yearbook of Women Entrepreneurs and Workers in Micro and Small Businesses" endorses that investigators analyzed gender profiles in small businesses from 2001 to 2011 and they reveal that female entrepreneurs in the country grew by $21.4 \%$ in this period (Stewart, 2013) ${ }^{15}$. In the yearbook, a technical Director emphasizes that:

"As business women, they can better reconcile their work with their obligations to take care of their homes and their children. Nearly half of these women are solely responsible for the education of their children, and that doesn't stop them from starting a business with dedication." 16

At present, it is notable the spread of entrepreneurship education as a subject in the curriculum of all educational levels, from preschool to high school. At the same time, it is important to mention the expansion of MBA's that focus on business management professionals in the country. However, Sebrae, since the early 1990s stands out as the main institution related to the promotion of entrepreneurship culture in Brazil.

It is worth to emphasize that, in the beginning of 2014's, was inaugurated the Sebrae Business School (São Paulo) the first public educational institution dedicated to offer courses about entrepreneurship at technical and graduation levels ${ }^{17}$.

13 Data taken from: Emcincoanos, número de mulheresnabolsacresceumais de setevezes. Patricia Alves. Portal InfoMoney. 07/08.

14 Data taken from: "Público feminino é arma da bolsa parareterpessoafísica". Valor Econômico, 26/03/2009.Free translation made by the author.

15 Data taken form: Women Entrepreneurs are on the Rise, Making it Work in Brazil. By Emily Stewart. October 15, 2013. In:http://pulsosocial.com/en/2013/10/15/women-entrepreneurs-are-on-the-rise-making-it-work-in-brazil/. Access: July, 2014.

16 Ibid.

17 Data taken from: http://www.sebraesp.com.br/index.php/239-uncategorised/institucional/escola-de-negocios. Access: August, 2014. 
Thus, entrepreneurship themes in schools and universities is a recent topic. There are no records of specific courses directed to women in these institutions. Besides the acting of Sebrae, regarding to entrepreneurship education of women, there are programs sponsored by the federal government and nonprofit institutions. In this case, it is noteworthy to highlight some projects in Brazil.

On the one hand, the "Mulheres Mil" is a program inserted into the set of public policy priorities of the federal government, in which aims to stimulate equity, access to education, and gender equality, especially, in the Northeast and North regions. Under three axes education, citizenship and sustainable development - the program seeks to provide social inclusion focused on autonomy and creation of alternatives workplace to improve the quality of their lives and their communities ${ }^{18}$.

Another program is the "10,000 Women" promoted by Fundação Getulio Vargas and IE Business School, launched in 2008, is a philanthropic initiative that seeks to bring business education for women and to improve the quality of their learning. ${ }^{19}$.

On the other hand, there are also initiatives from nonprofits associations, like the Association of Women Entrepreneurs (Brasilia) that seek to ensure the empowerment of women, as well as, to promote opportunities for the social and cultural equality between men and women. It is important to note that the courses offered range from computer, hardware, and telemarketing to courses like home services and caregiver for the elderly sector ${ }^{20}$.

In general, the stimulus to be an entrepreneur, proclaimed by the "gurus" and government institutions, emphasizes the importance of planning a career path that involves being a businessperson and financially independent. That means, women could be an autonomous worker, and they also could work in their own home; therefore, it is possible being a respectable mother and a virtuous housewife - "Generally, women are better able to achieve a balance between their personal and professional lives than men. In fact, many women go the entrepreneurial path in order to have more flexibility with their time" - elucidates a technical Director of Dieese in the reporter (Stewart, 2013).

However, these discourses obscure the underworld of informal and precarious labor, affecting in particular the lower classes. This phenomenon reinforces the traditional role of women and it supports the fact that they are working longer and harder than ever before. Far from the idea that women work for a salary or for their independence, most women work because they needed it.

These financial consultants have been infiltrated through different sectors of society, forming a particular dynamic. This movement has resonance in Brazilian society, because it resets the social roles in their place, that is, the women are 'backing home' to take care of families' money (Leite, 2012).

18 Data taken from: http://mulheresmil.mec.gov.br/index.php. Access: August, 2014.

19 Data taken from: http://www.10000mulheres.com.br/. Access: August, 2014.

20 Data taken from: http://www.amedf.org.br/. Access: August, 2014. 
The arguments employed by such consultants massively reinforce the needed for entrepreneurial motivation to achieve financial independence. However, such arguments appear strictly related to issues such as marriage, home, family, children, quality of life, etc. The advisors also report some financial family problems, and they consider a lack of financial understanding and poor money management skills that were not coordinated by the women.

These events indicate an interesting sociological phenomenon, in which the woman comes out of the labor market and back into the domestic sphere, that means, the women are coming back to their traditionally safe environment - the oikos.

Whereas, the "housekeepingt" is the role that historically was part of the women's activities, but, in this case, the female figure is seen not as a house manager, but as a kind of a home "investor". Apparently, this new phenomenon places the woman in her place of origin: the home.

We are watching a phenomenon that involves issues relating to the family; where the "cultural guide" preaches that women have to take care of their home and children, not only financially but also in a traditional way. The relationship between financial world and the role of wife/ mother can also be easily found in books that encourages entrepreneurship attitudes in Brazil.

By comparing books considered bestsellers in the United States with which are translated in Brazil, it is possible to note that the advices directed to women given by Brazilian intermediaries are not so aggressive related to some suggestions given by one of the most popular financial counselors in the United States.

The American financial guru uses aggressive and hostile language to give financial advices and to talk about money to the viewers' of her show. Overall, her aggressive style and the visibility she gives to the fact that she is lesbian apparently would not work in Brazilian society. After more than 10 years of success in the United States, there are no translations of her books to Portuguese. However, there is an adaptation of her financial guide "Women and Money," in 2009, realized by the principal financial advisor in Brazil.

In the preface of "Women and Money," the Brazilian author addresses that he agrees with the simple way she presents complex subjects such as finance for the public. However, he emphasizes that some opinions and suggestions made by Suze are clearly different from his arguments.

On the other hand, "Rich Dad, Pood Dad's", who also is one of the best-known American financial book - the author has a different attitude. His principles follows the form of a story, which tells the Rich Dad's path to get rich.

Thus, it is necessary to point out that the "adaptation" of ideas is a great evidence that outlines the "cultural guide," which conduct and attract individuals to the financial universe in which issues such as family, money, and wealth express a peculiarity of Brazilian society.

From the exposure of these facts, it is possible to argue that the construction of this new kind of economic figure is tied to the ideas that lead to family issues in Brazil, which becomes an apparatus for stability and security. This "new figure" annihilates the negative aspects of the 
entrepreneur, if he is greedy and individualistic, the new example should worry in accumulating wealth to enjoy and ensure your family's future. In other words, the expansion of the financial and entrepreneur practices is supported by Christian ideals about the strengthening of the family ties, which focus on the need for savings.

The appeals for the individuals to take control of their own financial independence symbolically legitimize foreign economic practices that was seen before as a negative skills. Thus, the financial advisors help to demystify the capital market, which gradually become a not "hazard" form of investment in Brazilian society.

There is a mechanism that operates both in the objective and in subjective spheres of society, in which sets up the legitimacy of the financial world in the country. The "new" economic culture that have been created is surrounded by family ethics and operates as an apparatus capable of changing social behaviors and sensitivities, ie, the habitus (Bourdieu, 1997), which, in turn, reflects social rearrangements and redirects the roles of individuals and family in society.

The advices instill in the public receptor a new perception about the financial world, leading individuals to believe that acting "economically" is a moral action. There is a moral influence being created to perform individual's actions that transforms attitudes and practices. Personal finance promoters have created a new social space, supported by performances, miraculous calculations, magic and science. Therefore, the idea about happiness and satisfaction is associated with the possession of money (Zelizer, 1994; Simmel, 1990).

The tremendous importance of money for understanding the basic motives of life lies in the fact that money embodies and sublimates the practical relation of man to the objects of his will, his power and his impotence; one might say, paradoxically, that man is an indirect being. I am here concerned with the relation of money to the totality of human life only in so far as it illuminates our immediate problem, which is to comprehend the nature of money through the internal and external relationships that find their expression, their means or their effects in money (Simmel, 1990: 211).

Historically, Donzelot (1986) demonstrates the importance of savings for the advent of working class families as a practice of discipline individual unruly behavior. The rebirth of the questions that refer to a temperance movement reinforces the meaning of the familialism concept (Lenoir, 2003), which suggests thinking "family" as a category that is integrated to financial sphere as a natural institution.

For this author, the meaning of "family" is dynamic, because, historically, it has been changing with the emergence of economic models and new forms of political and social organization. According to Lenoir, the family cannot be regarded as a principle of evolution, but as a product of economic, political and social context, in which it is possible to argue that the advance of financial and entrepreneurial practices also operates as a tool that "normalize" the routine of a family life - leading women to their traditional place.

It is noteworthy that other agents and institutions also contribute to strengthening the current ethics of the family as disciplinary rules of behavior (Foucault, 1994). For example, in Brazil, 
there is the "State", which formulates policies and programs of economic and social inclusion that values the family unit, and the Catholic Church, which carries out a campaign about the indissolubility of marriage, promoting ideas against the abortion, the homosexuality and the contraception, etc.

Similarly, it is possible to observe the expansion of neopentecostal churches, which strengthen the family entity as a synonym for professional and economic success; they try to establish a new meaning for "money", introducing economic topics such as entrepreneurship, business, personal finance, among others. At the Universal Church of the Kingdom of God, according to Mariano, the individual with financial problems are induced to participate in the ritual of prosperity, and, if he pay the tithe, he will receive pastoral councils, prayers, exorcisms, and promises of incentives for self-employed (Mariano, 1999: 60).

In the same way, the individuals, are called by the personal financial promoters, to reflect about the budget and to start carrying out a new financial plan, and also they are incentivized to initiate an innovative business. These prosperity churches are symbolic associated with financial and entrepreneur intermediaries, because culturally they are promoting new attitudes regarding the financial and entrepreneurial life. In fact, there is a formation of a "cultural guide" that admit the versions of different agents and institutions that figure the social space; however, we are watching a cultural progress of the finance and entrepreneur ideas proposed by unthinkable characters surrounded by an optimism culture and familialism ethics.

This brief scenario shows a specific reality in Brazil, the apparent link between this sector and family issues illustrates a peculiarity, which supports, respectively, the rise of the financial intermediaries and the legitimacy of the investment and entrepreneurs practice as a "natural" phenomenon.

The logic employed as an argumentative "sermon" operates as a symbolic violence (Bourdieu, 1997), which induces the individual to strictly control their daily economic practices. People are influenced by biases existing in the financial field, so become an entrepreneur and accumulate wealth; it is part of a natural human condition. The magic that makes up the formulas presented by the consultants has been linked to family metaphors of the universe that are used to justify the financial world (Lakoff, 1996), while concepts such as investment, uncertainty, instability and risk are been part of the individuals and families daily lives.

This dynamic opens way to reflect about transfer the analysis focused on socioeconomic aspects to the cultural field, but this finding may indicate that we are facing the rise of a conservative society, in which a new "order of justice" has been established in Brazil (Douglas, 1996; Grün, 1998). It is possible to observe the existence of an ideology that values the ethics of moral norms reinforced by economic inclusion of families disseminated by a variety of agents, which make up a sort of second nature, that is, a national habitus (Elias, 1986).

Gurus' performances help to instill in the public receptor a new perception about the financial world. According to Becker (1977), social norms are created by groups or individuals that are called "moral entrepreneurs." Therefore, these gurus are significant to spread new social values. They are "moral entrepreneurs" of financial and entrepreneurial education. 
The books and contents analyzed try to educate and to bring items to be copied - this could transformer the social meanings given to people and social activities. The mechanism used by gurus transforms individual in their collective experience and thus it contributes to the (re) production of habitus (Bourdieu, 1997).

There is a moral influence being created to perform individuals that transforms attitudes and modes of action. Financial education promoters have created a new social space, supported by performances, miraculous calculations, magic and science. Therefore, the idea about happiness and satisfaction are connected to the possession of money (Zelizer, 1994; Simmel, 1990) and linked with the notion of heteronormative family.

"When personal finance becomes the way in which ordinary people are invited to participate in that large abstraction called the economy, a new set of signals are introduced as to how life is to be lived and what it is for" (Martin, 2002). The argument supported by Martin reinforces what happened in Brazil. The personal finance advice creates an "obsession" for making money that dominates lifestyle, personal ambitions and decisions.

Consequently, the risk becomes part of everyday life (Martin, 2002). The moral entrepreneurs also use the argument that, currently, people have no more security in daily life. In a period, where instability and unemployment worries the population, personal finance books show cases of business or professional success based on self-help schemes and family triumph.

\section{Final considerations}

In recent years, there has been a proliferation of articles and books heralding this supposed phenomenon. It illustrates the emergence of financial guides services directed to individuals and families in Brazil. In general, these specialists, considered "gurus", search for guiding individuals toward changes, related to entrepreneurial motivations and practices of risky investments. Currently, these gurus teach about new careers, how to succeed a new enterprise, how to make money; in this sense, they also provide some recommendations about savings and investments.

The most recent studies related to entrepreneurship and women take into consideration researches that focus on the problems they face, their managerial practices, and their skills for success and gender differences. Specifically, the interest in understanding women's entrepreneurial activities is a result of the importance they are gaining in the entrepreneurial sector as well as evidence that women efforts are been associated with being an entrepreneur, securing their financial independence without leaving their traditional role as mother and as housewife.

In this regard, the results show, in what extent, publications on entrepreneurship and personal finance focused on women "magically" standardizes feminists ideals linked to the notion of material wealth (money) and financial independence, at the same time, it is strictly associated with moral values that defines the "traditional" role of women.

These financial consultants have been infiltrated through different sectors of society, forming a particular dynamic, for example, they are called to give lectures in neopentecostal churches, 
in this sense, the priests also have transmitted financial thoughts 'religiously' to their believers. This movement has resonance in Brazilian society, because it resets the social roles in their place, that is, an important evidence a is that the women are 'backing home'.

By these evidences, this paper presented that entrepreneur issues are been embedded in Brazilian society. It constitutes a kind of "cultural guide" that addresses a moral topic, supporting the idea of personal and financial success. These speeches are embeddedness by an optimism culture that encourages individuals to take economic choices that were not considered as a moral practice before.

\section{Author details}

Elaine da Silveira Leite*

Address all correspondence to: elaineleite10@gmail.com

Federal University of Pelotas, Brazil

\section{References}

[1] Apolinário, A. Silva, A. R. Diniz, C. E. M. Ribeiro, E. P. Capistrano, E. O. “O Impacto do FGTS na Alavancagem do Mercado de Capitais Brasileiro." In: XXII Encontro Nacional de Engenharia de Produção. October, 2002.

[2] < http://www.abepro.org.br/biblioteca/ENEGEP2002_TR34_1217.pdf> Web.

[3] Becker, Howard S. Uma Teoria da Ação Coletiva. Rio de Janeiro: Zahar, 1997.

[4] Bourdieu, Pierre. "Le Champs Économique." Actes de la recherché en Sciences Sociales. 119 (1997): 15-57.

[5] Bresser-Pereira, L. C. "State Reform in the 1990s: Logic and Control Mechanisms." In: Institutions and the role of the State. Cheltenham: Edward Elgar, 1 (1997): 175-219.

[6] Bresser-Pereira, L. C. and Grau, N. C. “Entre o Estado e o Mercado: o Público Não Estatal." In: O Público Não-Estatal na Reforma do Estado. Rio de Janeiro: Editora FGV, (1999): 15-48.

[7] Carvalho, A. G. "Governança Corporativa no Brasil em Perspectiva." Revista de Administração de Empresas. 37 (2002): 19-32.

[8] Carruthers, B. G. \& Espeland, W. N. Money, Meaning and Morality. American Behavioral Scientist, 41, 1384, 1998. 
[9] Crotty, J. "The Neoliberal Paradox: the Impact of Destructive Product Market Competition and Impatient Finance on Nonfinancial Corporations in the Neoliberal Era." PERI Research Brief. University of Massachusets, Amherst, 2003. Print.

[10] Donzelot, J. A polícia das famílias. 2ª edição. Rio de Janeiro, editora Graal, 1986.

[11] DOUGLAS, M. Thought styles: Critical essays on good taste. London:Sage, 1996.

[12] Elias, N. A Sociedade de Corte. Trad. Ana Maria Alves. Lisboa: Editorial Estampa, 1986.

[13] Erturk, I. Froud, J. Johal, S. Leaver, A. Williams, K. “The Democratisation of Finance? Promises, Outcomes, Conditions." Review of International Political Economy 14.4 (2007): $553-75$.

[14] Evans, Peter. Embedded Autonomy. States \& Industrial Transformation. New Jersey: Princeton University, 1995. Print.

[15] FOUCAULT, M. Dits et écrits. Paris: Gallimard, vol. IV, pp. 783-813, 1994.

[16] Grün, Roberto. GRÜN, R. A Classe Média no mundo do Neoliberalismo. Tempo Social, São Paulo, v.10, n.1. pp. 143-163, 1998.

[17] "Atores e Ações na Construção da Governança Corporativa Brasileira." Revista Brasileira de Ciências Sociais. 18 (2003): 139-161. Print.

[18] "A Evolução Recente do Espaço Financeiro no Brasil e Alguns Reflexos na Cena Política." Revista Brasileira de Ciências Sociais. 47 (2004): 5-47.

[19] “Decifra-me ou Te Devoro! As Finanças e a Sociedade Brasileira." MANA. 13 (2007): 381-410.

[20] "A Crise, a Guerra Cultural e as Surpreendentes Transformações do Espaço Econômico Brasileiro em 2009". In: Colóquio Internacional- A internacionalização das ciências sociais francesas e a cooperação científica com o Brasil. Working Paper, 2009.

[21] Harrington, Brooke. Pop Finance: Investment Clubs and the New Investor Populism. New Jersey: Princeton University, 2008.

[22] Lakoff, G. Moral politics: what conservatives know that liberals don't. Chicago: University of Chicago Press, 1996.

[23] LEITE, E. S. Reconversão de habitus: o advento do ideário de investimento no Brasil. Tese defendida no Programa de Pós-Graduação em Sociologia - UFSCar, 2012.

[24] Lenoir, Remi. Généalogie de la morale familiale. Paris: Seuil, 2003.

[25] Mariano, R. Neopentecostais: sociologia do novo pentecostalismo no Brasil. São

[26] Paulo, Loyola, 1999.

[27] Martin, Randy. Financialization of Daily Life. Philadelphia: Temple University, 2002. Print. 
[28] McGee, M. Self-Help, Inc.: Makeover Culture in American Life. London: Oxford University Press, 2005. Print.

[29] Paula, A. P. P. \& Wood T. Jr. "Pop-Management: Contos de Paixão, Lucro e Poder." Encontro de Estudos Organizacionais. 9.24 (2003): 39-51. Print.

[30] Preda, Alex. “The Rise of Popular Investor: Financial Knowledge and Investing in England and France, 1840-1880". The Sociological Quartely. 42 (2001): 205-232.

[31] SÁ, G. A revolução cultural no mercado acionário. Revista de Administração da USP, São Paulo, v. 38, n. 2, p. 112-125, abr/maio/jun, 2003.

[32] Simmel, George. The Philosophy of Money. New York: Routledge, 1990.

[33] Stewart, Emily. Women Entrepreneurs are on the Rise, Making it Work in Brazil. In: http://pulsosocial.com/en/2013/10/15/women-entrepreneurs-are-on-the-rise-makingit-work-in-brazil/. October 15, 2013. Access: July, 2014.

[34] Zelizer, Viviana. The Social Meaning of Money. New York: Princeton, 1994.

[35] Weber, Max. A Bolsa. Lisboa: Relógio d'água, 1984. 